Meta

Journal des traducteurs

Translators' Journal

\title{
The Form and Function of Repetition in Okot p'Bitek's Poetry
}

\section{Ogo A. Ofuani}

Volume 31, numéro 3, septembre 1986

Prismes de traductions littéraires

Facets of Literary Translation

URI : https://id.erudit.org/iderudit/003757ar

DOI : https://doi.org/10.7202/003757ar

Aller au sommaire du numéro

Éditeur(s)

Les Presses de l'Université de Montréal

ISSN

0026-0452 (imprimé)

1492-1421 (numérique)

Découvrir la revue

Citer cet article

Ofuani, O. A. (1986). The Form and Function of Repetition in Okot p'Bitek's

Poetry. Meta, 31(3), 300-313. https://doi.org/10.7202/003757ar d'utilisation que vous pouvez consulter en ligne.

https://apropos.erudit.org/fr/usagers/politique-dutilisation/ 


\section{THE FORM AND FUNCTION OF REPETITION IN OKOT P'BITEK'S POETRY*}

Okot p'Bitek needs no introduction on the African literary scene. His songs under consideration here are Song of Lawino, Song of Ocol and Two Songs (Song of Prisoner, Song of Malaya) ${ }^{1}$. They are all dramatic monologues - one-speaker poems in which the conflicts, confrontations, etc., are presented consistently from the point of view of the speaker.

Repetitions abound in p'Bitek's pœems. This is one of the observations a careful reader makes on initial reading. Such repetitions are considered rhetorical devices in the texts because they are of significant stylistic importance to the monologuers as they try to persuade us to adopt their viewpoints, to inform us, to achieve imaginative consent, and to engage our interests and guide our emotional responses as they address us. They seem unavoidable in such monologues if they are viewed as a story-teller's strategy, akin to digressions, for creating different effects, at different levels : phonetic, morphological, syntactic and situational. As poetic texts, repetitions seem to have a structural function as well.

A discussion of pattern in poetry, involves a discussion of repetition; rhythm, rhyme, alliteration and internal echoes are all repetitions of sounds; but the repetition of whole words or phrases is as much a part of the mental as of the physical form. In monologues, repetitions are also an effective device for expressing different moods. We tend to repeat ourselves when we are happy, angry or distressed, and we are also aware of the irritating nature of the careless use of repetitions (such as mannerisms) in ordinary conversation. The repetition of words is used for emphasis in all those situations in which they are used, both in normal everyday life and in the fictional life of the monologuers of p'Bitek's 'Songs"'. The repetition of a word or a phrase for the sake of this intellectual effect - to emphasize a fact or idea - is quite different from the purely magical (aesthetic) function of repetition in a refrain or chorus in songs ${ }^{2}$. Both effects are present in different degrees in the 'Songs'. It is our intention to explore their form and function in p'Bitek's 'Songs' in this paper.

One striking feature of repetition in the 'Songs' is that it is used as a foregrounding device, as an attention-drawing strategy. The emphasis that results differs from one singer to another, depending on their intentions. In Song of Prisoner, for example, the presiding judge's question, directed to the prisoner before he was committed to jail without trial, occurs four times (pp. 12, 30, 32, 44-45) :

Do you plead

Guilty

Or

Not guilty? 
The immediate physical position of the singer has been explained to us by his description (pp. 11-18). He asks the warder when he speaks to him in section one how he can beat such a weak man and asks the judge why he is punished before being found guilty. His questions explain the dramatic situation behind the pœem. But the significance of the refrain - like question reproduced above is that it is used in conjunction with the device of apostrophe to highlight the prisoner's problems, to dramatize the essential confrontation between him, the warders and the remembered figure of the judge ${ }^{3}$. More significantly, it is used to keep his problems constantly in the mind of the reader or listener. Each time the prisoner describes the punishment meted out to him by the warders or describes his bleak prison cell, the image of the judge, as the initiator of his plight in sentencing him to prison custody, comes to his mind. This refrain is not, like the rest of the monologue, addressed directly to the warders. It is a kind of interior monologue ; the speaker's mind is graphically represented for our benefit. Hence its intrusive pattern in the text is separated from the mainstream of the narration, typographically. Its emotional impact, the reader realizes, is that on such occasions, the physical strain combines with emotional and psychological torture, and his mind moves one moment to his intense pain, the next to his lowly birth, to the suffering of his children, and then to the desecration of his matrimonial bed by the rich chief. The effect of this type of presentation is that we suspend moral judgement as to whether he deserves his punishment or not but pity him for the degree of punishment suffered. It is immoral too for the judge to sentence him without trial and for the warders to beat him. (The warders are misusing the power entrusted to them by resorting to this type of violence.) As this constantly happens, the prisoner makes different pleas ("I plead guilty to...") which in turn underscore the initial effect.

For instance, in answer to the question quoted earlier, the prisoner on one occasion answers in the following words :

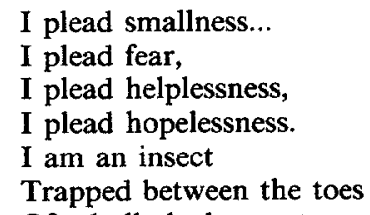

The pity we talked about is felt for the prisoner because of the critical role he adopts, a role manifested through his use of the very clear link that exists between irony and metaphor achieved through the repetition of the different abstract nouns (smallness, fear, helplessness, hopelessness). The phrase "plead (guilty) of..." is so restricted in English that what follows it must designate some kind of crime or misdemeanour : e.g. "plead (guilty) or arson", "plead (guilty) or theft", etc., are acceptable English expressions but not "I plead smallness/fear/helplessness, etc., ..." This is then the kind of violation of collocational rules which most commonly produce metaphor. The lack of collocation, the clash of semantic features, is at the level of register (legal, courtroom) ${ }^{4}$. From the clash of "plead (guilty) of ..." and "smallness, fear, hopelessness", there arises the equation CRIME = MISFORTUNE, analogous to the equation of tenor and vehicle in metaphor, except that here it is the contrast between the two that is brought to our attention, rather than the likeness. In the poem, therefore, the prisoner succeeds in evoking the reader's sympathy through this divergence between our expectations and what he actually says. He implies that he is on trial not for committing a crime but for being poor, helpless, and so on, associations which "guilty" would not normally bring to our mind. He adopts this pose in order to win sympathy for himself, and he succeeds. 
Thus, repetitions of this pattern have a textually cohesive function of constantly keeping in focus the central theme of the song : the prisoner's plight and the injustice of the authorities 5 .

Song of Prisoner also illustrates various other repetitions used with different results. The opening section reveals the man suffering in the cell. His psychological state is revealed in the images he uses to describe the cell and the numbing effect of the cold to which he has been exposed. The stone wall is described as if it is animate, and has a volition of its own, to torture him (personification) :

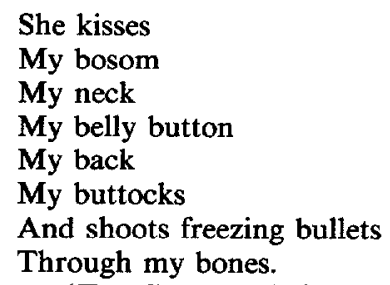

(Two Songs, p. 12.)

The repetition here is at several levels : phonological and structural. First, the phonetic, in the light of the verse as "song". Lo Liyong has described p'Bitek poems as mere meditations and therefore "unsingable"6. Okot p'Bitek himself has, surprisingly, agreed that "they cannot be sung", implying that the titles "song of..." were adopted to mean "a poem about..."7 The above lines, however, reveal one instance among many in which the lyrical aspects of this poem are highlighted, in spite of the absence of clues for their melodic reproduction. As song, the lines seem built on a formulaic pattern of repeated structures and sounds. The lines form a single coordinated sentence with a single grammatical subject ("she"), that performs the actions (kisses, shoots) to the recipient, the direct object ("my") - repeated six times. P'Bitek is basically a free verse poet and therefore his lines are not measured with a regular metrical pattern the way blank verse is measured with a regular metre. There is also no specific rhyme scheme, either. Lines 3 and 5 have two syllables; lines 1, 2, 6 and 8 have three syllables each ; line 4 has five syllables ; and line 7 has six. The absence of a regular rhythmic form is offset by other strategies : the combined use of alliteration and line-end pauses which in the end give the line a certain rhythm.

At the phonological level, the repetition of the sounds $/ \mathrm{m} /$ (in "my") and $/ \mathrm{b} /$ (in "bosom", "belly button", "back", "buttocks", "bullets", "bones") is alliterative. The repetition of the structure $M y+$ nominal word group has the effect of cataloguing. The deliberate slowness of the rhythm is metrically evocative of the slow and methodical spread of the cold as it virtually 'undresses' the prisoner in their unusual love tangle. The use of run-on lines here may make the reader produce the lines at a faster rate to reveal the urgency in the 'spread'. But even then, the end-pauses unmarked by punctuation and the repetition of "my" at the beginning of each line slows down the speed of reading. There is an almost mandatory pause when one is listing or enumerating in English, and despite the absence of commas, the reader 'supplies' such pauses (signalled by the line-ends). The personalization of the experience through the use of "my", makes the prisoner's plight more emotionally appealing to us. The rather unusual collocation of "she" (animate, human, third person singular pronoun) with "stone wall" (inanimate, concrete, object) and the different actions ascribed to the wall ("kiss", "embrace", "welcome", "lifts", "shoots") are striking in their unusualness. They tie in with the general pattern of the prisoner's potent sexual imagination and delusions in the pœm. 
The alliterative effect of the repetition of sounds in the preceding example can be compared with the different effect of similar forms in the following example from the same song. The difference one notices is typical of the variation in p'Bitek's use of parallel forms at whatever level. In section 2, the prisoner varies the pattern of his repetition :

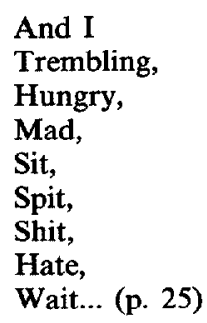

The stanza above, an epitome of the condensation of p'Bitek's verse which started in Song of Ocol, is used for the depiction of the prisoner's mood. After the first three lines, he adopts monosyllabic words as verse-lines. The commas add a thoughtful cadence, reflecting the progression in the stages of development, to the different actions and emotions. Even here, consonance as a phonetic poetic device, comes into play in the wordfinal $/ t /$ of "Sit/Spit,/Shit,/Hate,/Wait..." Assonance, in the repeated use of /i/ and $/ \mathrm{ei} /$, is also significant. The act of 'waiting' seems endless for the prisoner. The word "wait" is followed by four dots that indicate an agonizing infinity. (This typographical device is repeatedly used in all the Songs : three dots show intra-stanza suspension of trend of speech ; four dots indicate inter-stanza digression or suspension of speech, thought, etc.) So, for the prisoner, repetition is not just ornamental. Since alliteration plays an important part in common speech, it is probable that not all alliteration in poetry is deliberate, merely contrived. The prisoner, in this case, reacts as he would in real life, as his thoughts, moods and reactions change. The effect is that the reader cannot but be sympathetic - in mixing criticism with compassion, criticism for his social/ societal transgression that landed him in trouble in the first instance, through the murder of a political opponent, and sympathy because of his extreme punishment. ( $\mathrm{He}$ is not constitutionally guilty until they have proved his guilt.)

Malaya uses a refrain-like pattern similar to Prisoner's in her song. But its effect is different. She ends all her sections with the invocative format : "Sister Harlots, / Wherever you are ...", varying it by providing synonyms for "Harlot" ("Whores", "Prostitutes", "Malayas"). This is repeated ten times. Her exultation of other prostitutes tends towards flippancy. It is obvious that her 'case' is to satirise societal hypocrisy in sexual matters, especially the way people relate to prostitutes and 'use' them. But her casual tone tends to erode the seriousness of the plight of prostitutes and their 'threat' to the society that attacks them. She therefore occasionally sounds banal, vulgar, even obscene. As a result, she may be dismissed as irresponsible. (She is already a societal outcast by being a prostitute !) Adrian Roscoe's response to her is typical. To him :

'Song of Malaya' (i.e. Song of the Whore) can be quickly dismissed as a Rabelaisian jeu d'esprit, a holiday from commitment and a wasted opportunity, for Okot either refuses to see, or will not examine, the agonies of one of Africa's most distressing human problems. What is offered is a fleshly revel designed to annoy Sunday school teachers ${ }^{8}$.

This is one way of responding to p'Bitek's presentation of Malaya's case, and her use of this exultatory pattern. Other aspects of her presentation (like her casual description of her 'customers' and their equally varied natures and the different "smiles" she suitably adopts for them - pp. 155-156) may have helped to create this impression. But 
depending on how the critic views her Song, her usage may be interpreted to be deliberate, ironic ${ }^{9}$. The malaya (prostitute) is a multiple character. This makes it easy to misunderstand her. Now she is the hard, money-conscious professional (the stereotyped image of a prostitute), the next moment she is a fulfilled and very sentimental but angry mother, offering succour to her sons. Their irresponsible father has refused to accept them because of their society's double standards. Her wrath is directed at the perpetuators of this duality. Therefore, her exultation of her profession and exhortation of its practitioners may be designed to offend moral prudes who are not prudish enough to avoid sexually exploiting prostitutes. Her dragnet covers everyone from politicians, engineers and scholars to local chiefs, policemen, school teachers and their pupils. Her customers are multi-racial too. There is thus a universal note to her 'sexploitation' that she seems representative of the lot of prostitutes wherever they are as her refrain implies. Therefore, the more sensibilities she hurts, the more she derives the satisfaction of squaring with her detractors. But in reality, and in spite of our moral judgement, all she has done is to wield the tool of a satirist effectively - 'hit the nail on the head' but make the effect light with humour. Her exultatory repetitions are therefore functional and should not be taken too literally ${ }^{10}$.

The significance of praise-names and titles as part of the traditional repertory of p'Bitek's songs has been recognized by almost every reviewer. They are cited as influences from his traditional Acoli background, deriving from his interest in Acoli literary forms, particularly its poetry and songs ${ }^{11}$. But they have other functions, especially in reflecting the attitude of the addresser to the addressee. In the light of this paper, they are considered significant as repetitions because of their functions as compliments. They are, in such cases, adopted as a social strategy. Wolfson and Manes have observed that "complimenting has the underlying social function of creating and reinforcing solidarity between the speaker and the addressee"12. The theme which runs through all interactions of which complimenting is a part is the establishment of reaffirmation of common grounds, mutuality, or solidarity ${ }^{13}$. The singers in p'Bitek's Songs are aware of this function, and adopt them as rhetorical strategies.

In Song of Lawino, Lawino establishes that the conflict between herself and Ocol, her husband, is caused by his preference for the educated city-girl, Clementine. In spite of her rancour, she repeatedly uses praise-names and titles for Ocol. She calls him "Son of the Bull" (five times), "Son of the Chief" (four times), "Son of Agik" (once), "My friend" (three times), "My beloved" (several times), and pays such obviously flattering compliments as "You are a Prince" (p. 205), "Your grandfather was a Bull among men" (p. 206), "I used to admire him speaking English" (p. 22), and she admires features of his house decor, such as the wall clock ("To me the clock / is a great source of pride / It is beautiful to see" (p. 87).

A careful examination of some of the occasions when Lawino praises or compliments Ocol reveals that in most cases it is mock solidarity that is intended since they are already at variance. She uses them for two reasons. First, to show or attempt to show that she is still objective and unbiased in her assessment of their strained relationship (her acceptance of her "little jealousy", notwithstanding). Second, to convince Ocol that she is still on his side in spite of their misunderstanding : by tradition they are inseparable as man-and-wife, and so she is in a position to 'advise' him about the ways of the Acoli. The second reason lends significance to her suggestion that he could still be culturally redeemed, if he stops transgressing. But part of the communicative competence of native speakers of any language lies in their ability to recognise sarcasm, which changes what may appear on the surface to be a simple compliment into a joke or an in- 
sult. This is the function of some of Lawino's compliments to Ocol and Tina. In section 12 , for instance, she compliments Ocol in the following terms :

My husband has read much,

He has read extensively and deeply,

He has read among white men

And he is clever like white men. (p. 200)

Lexico-structural repetition plays a significant role here in defining and emphasizing Lawino's subject. The use of "my husband" in line 1 and its pronominal substitute "he" in lines 2, 3, and 4 leaves no doubt about who is being talked about. At another level, the verb "read" is used three times, and the adverbials "much", "extensively and deeply", "among white men" and "like white men" emphasize the extent of Ocol's reading. "White nen", in Lawino's traditional setting and understanding, are all-knowing. If Ocol is like one, if he has acquired their wisdom, then no praise can be greater! But that Lawino is being sarcastic, and does not intend to take this apparent praise of her husband literally, is revealed in the next stanza :

\author{
And the reading \\ Has killed my man, \\ In the ways of his people \\ He has become \\ A stump... (p. 200)
}

In this case, one would have expected Lawino to use a clear-cut contrastive transition term like "But" after the praise to show that she intends to portray the negative effect of Ocol's education. She instead uses the more neutral "And". But, here, it functions differently. It implies that Ocol's cultural estrangement and death is the consequence of his education and not in spite of it. Its effect is therefore stronger.

Lawino employs sarcasm, for the same effect, in describing her rival and her possessions :

Clementine has many handkerchiefs,

Beautiful handkerchiefs of many colours.

She ties one on her head

And it covers up

The rot inside... (p. 61)

Her intended sarcasm is bolstered by the repetition of the word "handkerchiefs" in lines 1 and 2. This type of lexical repetition foregrounds the repeated item, emphasizing it. The sarcasm lies in the negative associations she attaches to Tina's use of such a beautiful item of dress. It is "beautiful" and has "many colours" but these qualities contrast with the "rot" in Tina's head. So criticism rather than praise is intended.

The use of praises or compliments as masks for sarcasm is not the exclusive satiric tool of Lawino. Ocol uses it, too. One significant instance is his praise of African women in section 4. At the beginning of this section, he creates a devastating picture of "woman" as "carrier", "slave", etc. He condemns Adok Too, the blind poet, for praising her capacity for work by calling her a "camel". But half-way, he calls her "Sister/ Woman of Acoliland" and tells her to sever her links with the customs that enslave her. His outburst is surprising when he addresses her as :

You woman from Kikuyu land...

Lift up your head

Walk erect 


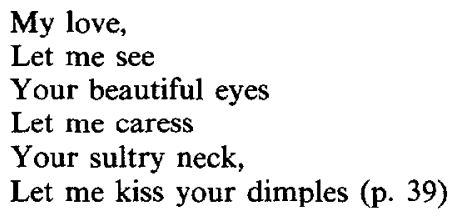

This outburst is inconsistent with the hitherto insolent tone he had used, from the beginning of the poem, in addressing "woman". The endearing vocative, "My love", seems out of place. We wonder if he really means what he says, or if it is some unguarded slip of real sentiments for her. We are surprised too that he scolds the "Bush pœt" from Kiambu and Nyeri to :

Cease insulting my wife

With your stupid song

My girl is not

A camel (p. 39)

But on subsequent reflection, we realize that he is only being sarcastic. His expressed sympathy for "woman of Africa" is not true. Endearments such as "my wife" and, particularly, "my girl" are out of place, considering his attitude towards Lawino. In actual fact, he insults her. The bush poets he attacks are her true friends, using traditional values which are meaningful in her Acoli context in praise of her, values from which Ocol is estranged because of his education and acceptance of strange forms. The camel is a symbol of physical endurance, meekness and obedience, images consistent with the traditional concept of womanhood. Further in the section, he continues with the usual pattern of his insults, and calls her "runner of errands", "cart", "donkey". His question, "Woman of Africa / What are you not ?", is the epitome of his attitude towards her : it summarizes all he has said, and is capable of saying, to insult her. The section ends with this conclusion :

\section{Woman of Africa}

Whatever you call yourself,

Whatever the bush poets

Call you

You are not

A wife! (p. 43)

The declarative tone of the last two lines, coupled with the emphatic note of the exclamation, show the finality of his conclusion, his dismissal of Lawino and African womanhood generally. He uses the same tone in section 6 , where he addresses the person he calls "my friend and comrade", whereas there are contextual clues that they are far from being friends and equals. His statements are therefore not to be taken on the surface.

The above are not the only repetitions the singers have used in their Songs. Others exist at the levels of syntax and lexis. They are usually in the form of repeated single lexical items, phrases, clauses, sentence patterns and even whole stanzas. They are not mutually exclusive but are part and parcel of a composite technique that helps make meaning in these texts. Thus the various functions of repetition overlap. For instance, syntax can be used to foreground or background the feelings of the singer : noun phrases can be placed in attention-catching positions for specific effects. The structure of the syntactic form of the texts, likewise, has a direct impact on reading : it may hold up the reader as he progresses linearly, left-to-right, through the text, or advance his progress 
smoothly ; or alternate these effects, directing attention more to some parts of the meaning, less to others. Thus syntax achieves various effects in poetry ${ }^{14}$. Syntactic repetition is a common method of adding to the musical quality of a poem, and giving it a regular structural pattern. The phonetic interpretation of the prisoner's repetition of "my" is both phonetic and syntactic, since, as explained, the item is the first-person singular possessive pronoun. It is also a lexical item in its status. Thus, it has phonetic, syntactic and lexical status (because it has lexical meaning).

Syntactic repetition in the Songs takes different forms. The most significant, contextually, is the repetition of sentence structures in the form of proverbs. As is common in most traditional settings, p'Bitek uses proverbs to bolster Lawino's arguments in her song. The most notable is the motif "Let no one uproot the pumpkin in the old homestead". This warning recurs after Lawino has put forward any important point or 'case'. Proverbs are usually employed in traditional orature for a special effect - they are employed to embellish the spoken word, and by so doing make words more convincing and more authentic : to give them the authority of the people's 'roots', their past, the anchorage of their culture. As the Nigerian novelist Chinua Achebe put it, proverbs are the "palm oil with which words are eaten"15.

In Acoli culture, the pumpkin metaphor has a significance which, as Ismael Mbise points out, is rooted in the environmental realities of the area they live in. Droughts are a familiar natural occurrence to the Lwo of Uganda, Kenya and Sudan and food is usually hard to get - the pumpkin often provides a source of sustenance. As he puts it :

During and soon after the heavy rains, the land looks beautiful and vegetation is all green. But during the dry season much of the vegetation either dies or becomes drought-dormant. If the year is hit by drought, very few edible plants are able to withstand the arid conditions. The most reliable of the biennal plants is the pumpkin, which many families in many parts of East Africa grow in their homesteads... All parts of the pumpkin are important... The worst damage this plant can suffer is to be uprooted from the soil ${ }^{16}$.

To uproot the pumpkin is therefore to destroy the security of the homestead, its source of food and to cause starvation - self-destruction for the uprooter, too. "Let no one uproot the Pumpkin" is therefore a significant philosophical statement which p'Bitek is using to encompass the sum total of cultural values. The pumpkin is therefore more than just a plant. Rubadiri, another East African, explains that uprooting the pumpkin is akin to destroying one's home, one's roots, to become deracinated :

If you uproot where you come from, then you have got nothing else... you are like the people who live in the towns, from one fiat to another because there is nothing to uproot except your valuable pictures ${ }^{17}$.

The East African cultural environment is therefore reflected in p'Bitek's poems via repeated cultural motifs.

But the pumpkin is thematically significant in the Lawino-Ocol conflict which is the message of Song of Lawino and Song of Ocol. The Lawino-Ocol conflict is a conflict between the Old and the New. Lawino is the 'protector' of her Acoli tradition with all its wisdom hence she is in a position to advise Ocol to stop his self-destroying act of uprooting the pumpkin in the old homestead. Ocol, on the other hand, is the rebel, fighting for a new social order, and to him the pumpkin is the symbol of the repressive past from whose bondage he has to break free - uprooting the pumpkin is symbolic for him in this sense. It is significant to note here that the pumpkin and the homestead go together. Each time both Lawino and Ocol refer to the pumpkin (the fruit), they tag along 
the homestead (its location) - that is to show that they are not referring to the wild fruits. The home-grown ones are culturally more symbolic.

But their attitudes towards these artifacts differ and are signalled by the way they describe them. For example, Lawino refers to the pumpkin four times and eight times to the homestead, while Ocol refers to the pumpkin twice and seven times to the homestead. To Lawino, the homestead, because of Ocol's neglect, is "deserted" (p. 13) but "old" (suggesting wisdom ?). To Ocol, the homestead is "old" but in the context of his insults, it is useless, decrepit. So most of the images with which he associates the pumpkin and homestead are negative, reflecting his own attitude of rejection : "old", "deserted", "dead", "demolished", "burnt". Thus, the pumpkin (and its homestead) is used to portray the "conflicting loyalties and belief structures" that form the basis of the Lawino-Ocol conflict $^{18}$. P'Bitek explores the conflicting claims of the Old and the New by means of these complementary personae - and this conflict is particularised in their attitudes to a significant aspect of the culture they share and would wish to protect and retain (Lawino), reject and destroy (Ocol), respectively. They maintain this dialectical opposition to the end. Okot p'Bitek does not resolve the painful tension between them with even a limited conciliation (in spite of Lawino's gesture at the end of her song). Their conflict has thus been portrayed as "a confrontation of irreconciliable and equally valid positions"19. Significant for this paper has therefore been the fact that the repetition of the pumpkin and homestead motifs helps to foreground this conflict, even across texts.

Two other motifs, at word level, are significant in the Songs because they are repeated across texts : they are the "Benz" car and the "Bull" motifs. The "Benz" motif has textual significance for Song of Ocol and Song of Prisoner. Just as Lawino, the village woman, has her counterpart in the city-girl, Malaya, so the two male characters are at polar ends of the status scale. Ocol is the university-educated elite, a member of the ruling class, one of the new "bulls" of the neo-colonialist period, while Prisoner is the underdog, a representative of the poor, the uneducated, the hungry, a representative of the criminal. For Prisoner and his group, the post-Uhuru period is one of disillusionment. Their pride and dignity have been denuded by the arrogance, trickery and violence of the "new masters". So where Prisoner is a spokesman for his group, Ocol speaks for his class. The classes have hatred for each other : Prisoner's, one of justifiable anger at the deception and neglect of the Ocol's, and Ocol, angry at the indolence and delusions of the lowly class who thought that Independence symbolised a period of miracles with bread falling from the trees. From their viewpoints, their anger is justified. Their attitudes, their contempt for each other, their inevitable conflict, is reflected in their different uses of the "Benz" motif.

In his Song, Ocol makes two references to the car (pp. 9 and 60). On each occasion, it serves an oppressive function. In the first, it is to help remove Lawino from the household ; she has been asked to "pack" and "go" ("Put all your things in it / And go !" - p. 10). In the second (section 6), Ocol is gloating over his successes and the "rewards" he has had from his education and his role in the Independence struggle. His attitude to his "friend and comrade" who represents the disillusioned persons of Prisoner's class, is that of condescension and patronage :

Reat the dust off your feet

And jump into my Merc.,

Let me take you for a ride

And show you my farm... (p. 60)

Here, the Benz is the epitome of the status symbol of the 'nouveau riche', hence Ocol's adulation (he prefers the affected form, "Merc. » - this clipped form sounds more inti- 
mate and cosy !). In the same section, he makes a statement that refers cataphorically (anticipates, predicts) the central theme of Song of Prisoner :

We have property

And wealth,

We are in power;

Trespassers must be jailed

For life,

Thieves and robbers

Must be hanged,

Disloyal elements

Must be detained without trial... (p. 63)

This is the situation in which Prisoner found himself. He is in jail without trial ; he has offended the ruling class of oppressors by killing one of them; he has really "trespassed against" the Ocols. As he languishes in jail, is beaten and tormented, he recaptures vividly the desecration of his matrimonial bed by the "wa Benzi", the car-owners (Malaya calls them "hunting car-men" - p. 142); the "Benz" becomes for him a symbol of oppression :

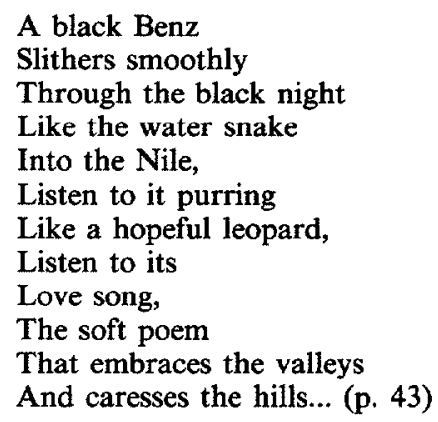

The "Benz" has all the agility of a feline and the smoothness of a snake ("slithers") and the cool (but calculated) satisfaction of a cat. But very significant is its sexual connotations. Its sound "embraces" the valleys and "caresses" the hills. It is not surprising that subsequent stanzas develop this sexual theme : the prisoner's bed "yells", his wife "giggles" and "shrieks" in the throes of sexual climax with the "big chief". This is the extreme of class oppression for Prisoner, it is a sacrilege :

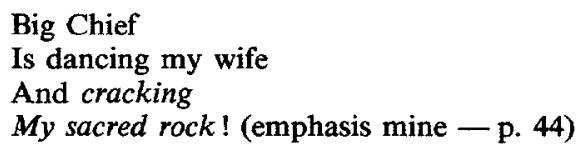

The next stanza is a repetition of the "guilty or not guilty" plea from the judge. To the prisoner, theirs is a class struggle - the "Big Chief" and the judge are members of the same oppressive group.

Annemarie Heywood has given an inevitable socialist interpretation to the "Benz" metaphor in Song of Prisoner. She points out that the Mercedes is a stunning metaphor of what Franz Fanon calls the "libidinal tie of the second nature" of man when he says :

The so-called consumer economy and the politics of corporate capitalism have created a second nature of man which ties him libidinally and aggressively to the commodity form ${ }^{20}$. 
Heywood sees the Mercedes, the commodity form at its most ostentatious and recognizable as is metaphorically exhibited in Prisoner's description, as "literally the vehicle of this secondary libido and aggression". In this metaphoric process, the singer's anguished mind has made a leap into recognition, and is also therewith casting off the chains of his secondary nature - a process which in turn, as Fanon is at pains to demonstrate, leads to a release of the "primary aggressiveness on an unprecedented scale"21. And so we find the singer, the impotent watcher in the grass, exploding into a desire which is wholly and radically destructive :

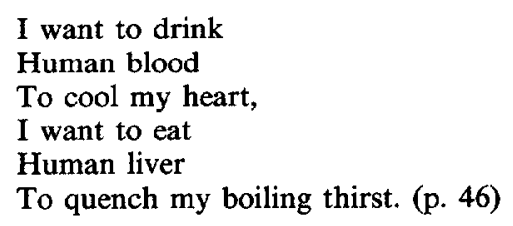

The bull, a traditional motif, has this kind of dual interpretation as well. It is used in all the Songs. In the Acoli context, the bull is a symbol of strength. So Lawino uses it as a praise name for Ocol and his lineage ("Son of the Bull"). She too has royal blood in her veins and the bull features in her own praise-names (She is "the daughter of the Bull" - p. 34). But in the later songs, the bull acquires a second, negative meaning. It is used as a symbol of strength, but this power is thwarted, it is the oppressive and violent power of the elite. It, for example, reminds Prisoner of the class struggle between the poor oppressed and the powerful, in a situation in which the powerful usually win. But, Prisoner, optimistically, hopes the weak would, for once, win :

Two bulls wrestle

With their horns,

The horn of the ruling bull

Breaks

And he tumbles down

The smooth breast

Of the hill

And plunges

Into the river. (Emphasis mine - p. 70)

It has to take a coup d'état of the type Prisoner envisages before the status quo can change.

Finally, at this level of discussion, comes p'Bitek's predilection for other patterns repeated. The interrogative and imperative forms of sentences are used in all the Songs. The interrogative form consists of two main types : the straightforward question desiring an answer, and the rhetorical question, a question asked, not to evoke reply but to achieve an emphasis stronger than a direct statement. The second type is mostly used in persuasive discourse and all the singers use it. The two female characters, for instance, adopt such question forms in summing up their arguments on the inevitability of men's natural desire for women, though from different perspectives (Lawino seeks to know "who has discovered the medicine for thirst", a euphemistic reference to sexual urge, Song of Lawino, p. 27 ; while Malaya in her Song, asks to know "who can command / The sun / Not to rise in the morning ?", p. 184). But we discuss imperatives in more details here because they have received little attention in discussions of p'Bitek's Songs. 
In the last section of her Song, Lawino addresses her culturally 'dead' husband once again. Where the penultimate section had ended on a note of pessimism (p. 208), this one brings in a new note of optimism. It opens with Lawino's reassurance :

But Ocol, my husband,

If you are not utterly dead

And fit only for the stomach of the earth, ...

Let me prop you up,

Drink some fish soup

Slowly, slowly

You will recover. (pp. 209-210)

The use of the transition term "But" at the beginning of this section, performs a textually cohesive function : it relates backwards but contrastively to the mood earlier expressed in. the penultimate section. It suggests that "in spite of what was said earlier" about Ocol, there is hope. On this optimistic note, the culturally live Lawino suggests remedies for Ocol. These remedies are in the form of the imperative structure, viz : "Let them...", "Ask them...", "Ask for...", "Pray that...", etc. that pervades the whole section. Lawino's suggestions are in the form of commands. It is so she seems to imply, because she is in a position to know (and he does not know) what is good for him. So she lets him know in the form of instructions. Here, her antagonism wavers, and her attitude is that of a more mature person addressing the prodigal. The commands she adopts here are, therefore, consonant with her new mood. Thus her Song ends with the patronising and conciliatory tone most readers recognise. But even to the end, she still lets him know that it does not pay to transgress against his culture :

Let me dance before you,

My love,

Let me show you

The wealth in your house,

Ocol my husband,

Son of the Bull,

Let no one uproot the Pumpkin. (p. 216)

There is no doubt that even this last statement ends on the imperative note we have talked about, as shown by the "Let me..." pattern repeated in lines 1,3 , and 7 . "Let no one uproot the Pumpkin" provides the basis of Lawino's argument throughout the poem and it does not seem an accident that it remains the final warning in the confrontation.

On the other hand, Ocol uses imperatives for a different effect. His rudeness and insolence towards his wife reflect in his delight in using brusque commands (of the directive kind). He uses them not only to emphasize a point, but they act as indicators to his personality. His Song begins with imperatives that direct Lawino to "pack and go". He is unbending, uncompromising. He uses imperatives throughout his Song - preferring words like "let", "listen", "cut", "lift", "burn", "walk", "cease", etc. (as on p. 39). This is grammatically marked by the preponderance of the simple present imperative mood (the imperative finite verb without endings for number or tense). The result is that Ocol is shown by his language to be emotional, angry, and going to "command the break up of Acoli tradition" which Lawino strives to uphold 22 . Ocol's use contrasts with Lawino's. When she tells us to "listen", to "look", and to "come", she gives us the whole associative culture of her ancestors (as in her use on pp. 71-72) where she shows Ocol round her parents' home pointing out all the culturally significant household wares). In a word, she has a tradition to cling to. Ocol has none. This dichotomy exists in their use 
of imperatives, just as it exists in the use of lexical items and sentence structure. Thus, grammatical structure is made consonant with character revelation in the songs.

The various patterns examined above are a mere sample of the possibilities in p'Bitek's Songs. The attempt has been to both identify and account for the presence of repetition as a rhetorical device in the pœms. P'Bitek's Songs are in free verse, meaning that they lack most of the conventionalised, technical and thus 'poetic' features such as rhyme and a consistent rhythm (say the iambic pentametre of blank verse which Milton prefers in Paradise Lost). The Songs have grave themes in spite of the 'indiscipline' often associated with free verse. But such verse has its own advantages - it lacks the stilted nature and often artificial constraints (such as stiff inversions) imposed on the poet by more technical forms. P'Bitek seems to prefer it because it gives a casual, everyday tone to the poems, a tone which makes the effect of the ironic presentation of the personae in the Songs more striking. The colloquial style of his Songs is suitable for the expression of difficult thought, anger, scorn, or sometimes of cynicism or the man-of-the-world attitude (as in Malaya's Song). Such a colloquial verse has a ring of great sincerity and naturalness, and thus suitable to the intentions of the monologuers whose main aims are to justify their positions and attempt to 'sell' their points of view to the addressees. To achieve this, a reasonable degree of pattern and discipline is given to the verse through the internal pattern of sounds, the choice of exact words and the effect of associations which give it its beauty. Such patterns most often involve repetition at the different levels discussed above. Repetition, therefore, helps to add artistry to a verse form that is often deemed artless, and p'Bitek himself has exhibited mastery in its poetic exploitation.

Notes

* This paper is based on an earlier version presented to the Third Annual International Conference on African Literature and the English Language, University of Calabar, Nigeria, 3-7 May, 1983.

1. Reference is to the East African Publishing House, Nairobi, versions of these Songs : Song of Lawino (1966), Song of Ocol (1970), and Two Songs (1971). Subsequent references will be made to these editions.

2. See Marjorie Boulton, The Anatomy of Poetry (London : Routledge \& Kegan Paul, 1953), for a fairly detailed and general discussion of the intellectual and magical effects of repetition in English poetic texts.

3. G.A. Heron, The Poetry of Okot p'Bitek (London : H.E.B., 1976), has a detailed analysis of the use of the device of apostrophe in p'Bitek's poms.

4. The term register refers to a configuration of the situational categories of field, mode, and tenors of discourse : variety according to user's use. See Michael J. Gregory (1967) : "Aspects of Varieties Differentiation", Journal of Linguistics 3, pp. 177-198.

5. I have elsewhere discussed in some detail the significance of lexical cohesion in this Song. See Ogo A. Ofuani : "Lexical Cohesion in Okot p'Bitek's Song of Prisoner", in Proceedings of the Seventh Ibadan Annual African Literature Conference, University of Ibadan, August 1982 (forthcoming).

6. Taban lo Liyong (1971) : "Review : Okot p'Bitek's Two Songs", Dhana '71, Nairobi : Makerere Printery, pp. 59-61.

7. See p'Bitek's interview with Petersen's class at the University of Aarhus, Denmark, in November 1977, in Kunapipi, Vol. 1, No 1 (1979), pp. 89-93.

8. Adrian Roscoe (1977) : Uhuru's Fire: African Literature East To South, Cambridge : C.U.P., p. 54.

9. For an alternative view of Malaya, see Ogo A. Ofuani : "The Image of the Prostitute : A Reconsideration of p'Bitek's Malaya", Kunapipi (forthcoming).

10. P'Bitek's presentation of Malaya (and Ocol) calls to mind Jonathan Swift's ironic presentation. The authorial intentions are the same - to shock the readers into realization!

11. Notable are Heron (1976) and G.H. Moore : "Okot p'Bitek : The Horn of the Grasslands", paper presented to the Fourth Ibadan Annual African Literature Conference, University of Ibadan, July 1979.

12. Nessa Wolfson \& Joan Manes (1980) : "The Compliment as a Social Strategy", Papers in Linguistics $13: 3$, p. 391 .

13. R. Brown \& A. Gilman (1960) : "The Pronouns of Power and Solidarity", in Paolo Giglioli (ed.) (1970) : Language and Social Context, Harmondsworth : Penguin Books, pp. 283-308.

14. Some of these functions are elaborated in Vilas Sarang (1970) : "Syntactic Nuances in the Poetry of W.H. Auden", Journal of the University of Bombay, Arts Number, Vol. 39, No 75, pp. 66-101. 
15. Chinua Achebe (1965) : Things Fall Apart, London : H.E.B. - with introduction and notes by Aigboge Higo, p. 5.

16. Ismael Mbise (1979) : "The Struggle for Identity in Selected East African Literature and Art", Ph.D. dissertation, University of York, Toronto, Ontario, May, pp. 70-71.

17. David Rubadiri (1971) : "The Development of Writing in East Africa", in C. Heywood (ed.), Perspectives on African Literature, London : H.E.B., p. 155.

18. Annemarie Heywood (1980) : "Modes of Freedom : the Songs of Okot p'Bitek", The Journal of Commonwealth Literature XV:1, p. 66.

19. Ibid., p. 67.

20. Franz Fanon (1965) : The Wretched of the Earth, p. 20. Quoted in Heywood, "Modes of Freedom...", p. 78

21. Heywood, "Modes...", p. 74.

22. G.H. Moore (1979) : "Okot p'Bitek : The Horn of the Grasslands". 